\title{
The Effect of Rangeland Attributes on Milk Yield in Rangeland Dependent Dairy Cattle Farms in Erzurum Province of Turkey
}

\author{
Running Title: Effect of Rangeland Attributes on Milk Yield of Grazing Cows
}

\author{
Abdurrahman Kara \\ Department of Soil Science and Plant Nutrition, Faculty of Agriculture, Dicle University, Turkey
}

Copyright $\bigcirc 2016$ by authors, all rights reserved. Authors agree that this article remains permanently open access under the terms of the Creative Commons Attribution License 4.0 International License

\begin{abstract}
This study was conducted in purposively selected villages in Erzurum in 2006 in order to determine the effect of rangeland and grazing cow attributes on daily milk yield per cow in rangeland dependent dairy cattle farms. Milk yield was recorded in about 10 study farms in each study village from early June to late September. Farms were visited monthly to check the milk records. In order to be able to see the effect of supplement feed during grazing period, study farms were provided with concentrates to be given one $\mathrm{kg}$ daily to lactating cows during the study. Vegetation studies were conducted on carefully selected 12 stops in relatively homogenous areas to represent the village rangelands using Modified Wheel Point Method. Rangeland condition values were calculated based on the vegetation studies in the selected villages regarding the nutritional value of the rangeland plants. Schooling years of the farmers, rangeland condition, bare ground, supplement feed during grazing period, cow breed, lactation order, days of the milking records, closeness of water spots to grazing sites and shading shelter availability were the variables considered in the study. In analysis of the data Least Squares with Dummy Variable techniques were employed. Analysis of the data revealed that schooling years of farmer, rangeland condition and shading facility had significant positive effect on milk yield as the effect of bare ground was significant and negative.
\end{abstract}

Keywords Dairy Cattle, Milk Yield, Rangeland Attributes, Education Level of Farmer, Erzurum

\section{Introduction}

Eastern Anatolia region is one of the 7 geographical regions of Turkey which covers the eastern most provinces of the country. It looks more advantageous than the other regions when pronouncing extensive animal production due to its vast permanent rangeland and meadow asset. In this region cultivable land is limited because of very broken and rugged geography. Moreover, quite long and harsh winter conditions limit the crop pattern. Nevertheless, since the other economic sectors are not developed well, economy is naturally dependent on agriculture as it relies mainly on animal production. Actually, although this region is seen more advantageous in terms of natural rangeland asset which constitutes about one third of the country total [1], long and harsh winter conditions are an important limitation for animal production as much as for crop production.

Since the roughage production is not sufficient to fulfil the need of the animals had to be kept inside in winter time, natural rangelands of the region are grazed early in the spring as soon as snow cover disappears. Early, over and irregular use of the rangelands over the decades resulted in deteriorations, degradations and in turn losses in roughage production potentials. Rehabilitation of the degraded rangelands means an increase in beef and milk production for the peasants whose livelihood depends on animal production in the region. This study was carried out to attract the attention on rangeland rehabilitation studies and to contribute to the existing knowledge within the context of rangeland condition-animal production relationship. To this end, the effects of rangeland attributes, along with the effects of some socioeconomic factors and some attributes of grazing cow on daily milk yield (DMY) of grazing cow were examined. 


\section{Material and Method}

\section{Material}

Vegetation study results, daily milking records of the lactating cows in the selected farms and daily shepherd records in study villages were the primary study material. Also, official records of the Eastern Anatolia Agricultural Research Institute and other relevant official institutions were used as secondary material in the study.

\section{Method}

Selection of the villages: In selection of the study villages special emphasis was given on their representation ability of the surrounding area and so the province as a whole. To this end, villages from different districts in the directions of East-West and North-South were selected purposively from those free from nomad movements and boundary problems, and from those of which their rangeland circumscription and allocation studies were completed. So, from Aşkale, Yakutiye, Tortum, Narman, Pasinler, Köprüköy and Horasan districts in total of 11 villages were selected for the study. However, in this paper were used the data for only the five villages (Taşağıl, Yayladağ, Şehitler, Tipili and İncedere) where shepherd records were successfully obtained. In the study area altitude of grazing sites varies between $1831 \mathrm{~m}$ and $2847 \mathrm{~m}$ asl. Average annual rainfall was realized to be $357.4 \mathrm{~mm}$ in 2006.

Vegetation studies: Vegetation studies were carried out in 2006 in order to determine the village rangelands' botanical compositions and so rangeland quality degrees. They were conducted in relatively homogenous 12 sites in each study village with four replications along the lines of $100 \mathrm{~m}$ in East, West, South and North directions according to the method explained by Koç and Çakal [2]. Moreover, rangeland condition was determined according to Rangeland Quality Degree method described by De Vries et al [3], cited in Koç et al. [4] using the vegetation study data for each site in every study village. Arithmetic means of 12 sites in each village were accepted to be the village's overall rangeland condition value. In this method rangeland condition has a value between 0 and 10 (indicating 0-2: very poor; 2,1-4,0:poor; 4,1-6,0: moderate; 6,1-8,0: good and 8,1-10,0: very good).

Milking records: About 10 volunteer study farms in each study village recorded the milking data twice a day during the study. Study farms were visited monthly to check the milking records. In the study area, except early spring and late autumn, supplement feed is not given to grazing animals during grazing season [5]. In order to determine the effect of supplement feed during grazing season on DMY of the lactating cows, each lactating cow was given one $\mathrm{kg}$ of manufactured milking concentrate (minimum 16\% crude protein and $2400 \mathrm{Kcalkg}^{-1}$ metabolic energy) daily during the grazing season for 120 days from the beginning of June to the end of September. To this end, about half of the study farms were provided milking concentrate. In order to ensure the same amount of concentrates to be given, each farm was provided with a pan in a capacity of one $\mathrm{kg}$ concentrate. In data analysis, milking records from the period of June-September were used.

Grazing Sites Records: In the study villages, shepherds who drive the village herds to graze were provided with notebooks to daily record the information about the site of grazing i.e. distance to village, closeness of the drinking water spots, availability of the shading shelter, etc.

Data analysis: The records obtained from the relatively homogenous 12 different sites with four replications were evaluated together to calculate the rangeland quality degree (RQD). The arithmetic mean of the RQD's calculated for all 12 stops were taken as the overall rangeland condition of the study village. In analysis of the data descriptive statistics and multiple regression analysis with ordinary least squares (OLS) technique were employed.

Multiple regression models with OLS estimation was preferred due to following reasons.

1. In psychology, biology and especially in economics, the assumption of ceteris paribus, which means "with other things being equal or held constant," is important in determining causation.

2. Since the most variables of interest are affected by more than one cause in real world it is important to isolate multiple independent variables affecting the dependent variable in the model of interest. The ceteris paribus assumption provides this utility.

3. As also defined by Gujarati $[6,13]$ linear regression is the workhorse of the econometrics and ordinary least squares (OLS) method is the most popularly used method to estimate the regression coefficients and best describes the relationship between dependent and independent variables in the presence of ceteris paribus assumption.

4. The regression coefficients, the linear estimators are easier to understand and deal with. It is easier to explain the effect of independent variables on dependent variable

5. It should be noted that the term "linear" in the linear regression model refers to linearity in the regression coefficients, not linearity in the $\mathrm{Y}$ and $\mathrm{X}$ variables [6].

6. In linear regression $\mathrm{Y}$ and $\mathrm{Xs}$ can be logarithmic, reciprocal or rose to a power if necessary. Since the quality of the model was not improved with other alternative models, especially logarithmic and semi-logarithmic models, and that interpretation of the regression coefficients is easier. So, in present study multiple linear regression was used to reveal the effects of the independent variables on daily milk yield of the grazing cows with flat values of $\mathrm{Y}$ and Xs.

Linear regression model can be written as in the formula given below [6];

$$
Y_{i}=\beta_{1}+\beta_{2} X_{2 i}+\beta_{3} X_{3 i}+\cdots+\beta_{k} X_{k i}+u_{i}
$$

Where;

$Y$ denotes dependent variable 
$X$ denotes explanatory (independent variables)

$\beta_{1}$ denotes intercept

$\beta_{2}$ to $\beta_{k}$ denote slope coefficients

$k$ denotes $\mathrm{k}^{\text {th }}$ coefficient

$i$ denotes $\mathrm{i}^{\text {th }}$ observation

$u$ denotes random or stochastic error term

In linear regression analysis following assumptions should be met;

a) There is no exact linear relationship (multicollinearity) among independent variables,

b) Error term has a constant (homoscedastic) variance,

c) Error terms are not correlated with each other, that is, there is no autocorrelation among error terms.

d) Error terms are normally distributed.

Without doubt there are a number of factors affecting DMY of the grazing cows of which some are related to the attributes of the grazing animals and the rangeland itself as some others are related to the farm and farmer. In the model, some independent variables investigated were categorical in nature and they were represented with dummy variables [6-8]. DMY per head is thought to be the function of the following continuous and discrete variables.

Daily milk yield $=f$ (rangeland condition, percentage of bare ground in village rangelands, days of the milking records, lactation order, cow breed, supplement feed, access to water, shading facility).

$$
\begin{array}{r}
Y=\beta_{1}+\beta_{2} X_{2}+\beta_{3} X_{3}+\beta_{4} X_{4}+\beta_{5} X_{5}+\beta_{6} X_{6}+\beta_{7} D_{7} \\
+\beta_{8} D_{8}+\beta_{9} D_{9}+\beta_{10} D_{10}+\beta_{11} D_{11}+e
\end{array}
$$

Where;

$$
\begin{aligned}
& \text { Y (Daily milk) } \\
& \mathrm{X}_{2} \quad \text { (Schooling) } \\
& \mathrm{X}_{3} \quad \text { (Range condition) } \\
& \mathrm{X}_{4} \quad \text { Bare ground (\%) } \\
& \mathrm{X}_{5} \quad \text { (Lact order) } \\
& \mathrm{X}_{6} \quad \text { (Day) } \\
& \text { Di } \\
& \mathrm{D}_{7} \quad \text { (Crossbred) } \\
& \mathrm{D}_{8} \quad \text { (Purebred) } \\
& \text { D9 (Concentrate) } \\
& \mathrm{D}_{10} \quad \text { (Access to water) } \\
& \mathrm{D}_{11} \quad \text { (Shading) } \\
& e \\
& \begin{array}{c}
\text { Daily milk yield of grazing dairy cattle } \\
\text { (litres/head) }
\end{array} \\
& \text { Schooling years of the farmers } \\
& \text { Rangeland condition (RC) } \\
& \text { ( } 1 \text { = Crossbred; } 0=\text { Others }) \\
& \text { ( } 1 \text { = Purebred; } 0=\text { Others }) \\
& \text { Supplement feed during grazing season }(1= \\
& \text { Yes, } 0=\text { No) } \\
& \text { Accessibility of water for animals in grazed } \\
& \text { site }(1=\text { Near, } 0=\text { Far }) \\
& \text { Availability of shading facility in grazed site } \\
& \text { ( } 1=\text { Exist, } 0=\text { No) }
\end{aligned}
$$

Data for the variables of DMY, lactation order and animal breed were obtained from the study farms through daily milking records as the data for variables of rangeland attributes (i.e. rangeland condition, bare ground) were from vegetation studies. On the other hand, the data for the variables of closeness of water spots and availability of shading shelter for the animals in the grazed sites were from the shepherd records.

As stated earlier, in obtaining the regression models, Ordinary Least Squares (OLS) technique was employed. F test was used to test the significance of the model as a whole. In this study, cross-sectional data was used and due to the nature of this type of data heterogeneity is more often seen as the problem violating the homoscedastic variance assumption of the data. So, heteroscedasticity was tested with Breusch-Pagan test and normality assumption for the error term of the model was controlled with Skewness and Curtosis test and graph method. Multicollinearity was tested with variance inflation factor (VIF). Since autocorrelation is the problem of time series data and the data used in the present study is cross-sectional autocorrelation was not tested $[6,9]$.

Because the relationship between DMY and lactation order was quadratic (Fig. 1), quadratic term of the lactation order (lactation order-squared) was included into the OLS model in order to improve the quality of the model. In statistical analysis of the data Stata SE 10 software package was used.

Normality test for the dependent variable failed according to Skewness and Curtosis test, but graphical methods justified that deviation from the normal line is trivial. In fact, these small and negligible deviations can be disregarded since they may have no real effect on the linear regression test even though the normality test may detect these negligible deviations to be statistically significant in larger sample size [10]. In another words, it gets harder to meet the normality assumption as the sample size increases the probabilities decrease since even small differences are detected. For that reason, normality can be a problem when the sample size is small [11].

Farmer age and stocking rate variables were also initially included to the first model but due to high VIF values indicating serious multicollinearity problem these variables were dropped. So, the model did not have a serious multicollinearity problem since variance inflation factor (VIF) calculated for the explanatory variable varies between 1.03 and 2.00 with an average of 1.41. However, after inclusion of the quadratic term for the lactation order variable relatively high VIF values were calculated for the lactation order and lactation order-squared variables, 8,77 and 8,77 respectively with an average of 2.93 . Nevertheless, it can be accepted that the model still does not have a serious multicollinearity problem since none of the VIF values exceeds $10[6,7,12]$.

However, because of the nature of cross-sectional data the model has heteroscedasticity problem $(\mathrm{p}<0.01)$. So, in order to correct it the regression analysis was performed using the Robust Standard Errors procedure [13].

\section{Results and Discussion}

\section{Vegetation Survey Results}

In total, 108 different species were determined in the 
rangelands of the study villages (Taşağıl, Yayladağ, Şehitler, Tipili and İncedere settlements), of which 22, 18 and 68 were of legumes, grasses and other families, respectively. The most common legumes were determined to be Medicago varia (4.88\%), Astragalus lineatus (3.74\%), Trifolium hybridum (3.27\%), Coronilla varia (1.63\%), and Astragalus microcephalus $(1.28 \%)$. The most common grasses were Festuca ovina (13.25\%), Stipa lagascae (3.04\%), Agropyron intermedium (2.37\%), Bromus tectorum (1.48\%), Dactylis glomerata (1.48\%), Phleum montanum (1.39\%), and Poa nemoralis $(1.12 \%)$.

On the other hand, Thymus pubescens (6.54\%), Salvia candidissima (3.27\%), Achillea millefolium (2.75\%), Galium verum (2.40\%), Artemisia spicigera (2.22\%), Eryngium campestre $(2.13 \%)$, Teucrium orientale $(2.13 \%)$, Tanacetum balsamita (2.10\%), Alyssum pateri (2.04\%), Helichrysum plicatum (1.68\%), Acantholimon caryophyllaceum (1.61\%), Plantago atrata (1.50\%), Sangiosorba minor (1.48\%), Euphorbia virgata (1.34\%), Tragopogon aureus (1.32\%), Taraxacum officinale (1.19\%), Potentilla bifurca (1.10\%), Verbascum cheiranthifolium (1.07\%), and Anthemis cretica
$(1.03 \%)$, were common species of other families.

\section{Descriptive Statistics Results}

The distribution of the lactating cows by breed in the study farms was $30.3 \%, 63.7 \%$ and $6.0 \%$ for indigenous, crossbred and purebred, respectively. The average number of lactating cows per farm was $6.3 \pm 0.05$ head with a range from a minimum of $5.0 \pm 0.06$ head in Incedere village to a maximum of $7.8 \pm 0.18$ head in Şehitler village.

Lactation order of the cows had value between 1 and 13. Rangeland condition value of the study village rangelands varied from 2.53 to 4.18 , indicating poor to moderate conditions. About $24 \%$ of the rangeland area was bare without any plant cover.

Fig. 1, illustrates positive relationships between daily milk yield (DMY) and RC, DMY and schooling years of farmers and the negative relationship between DMY and bare ground as it represents quadratic association between DMY and lactation order.
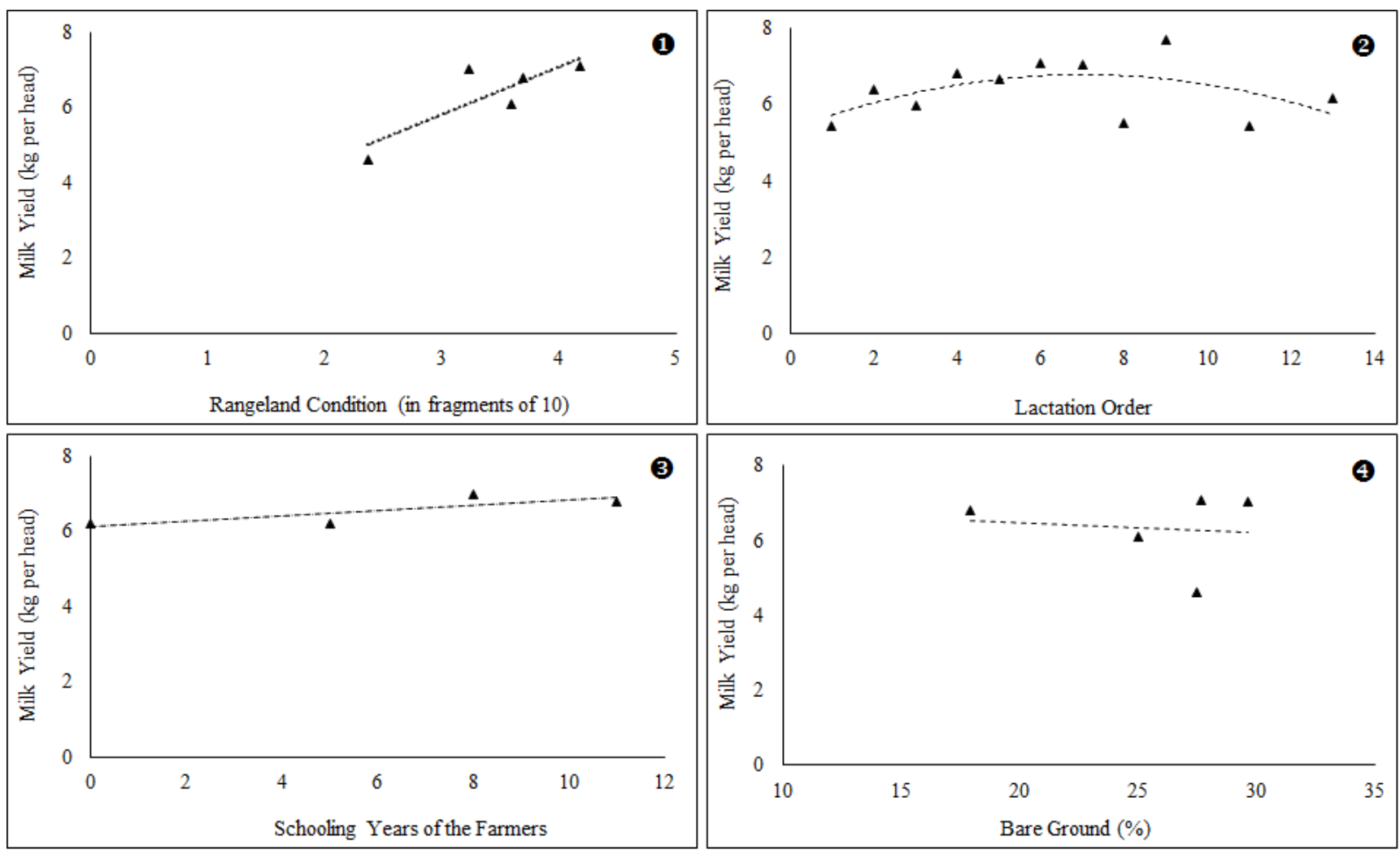

Figure 1. Relationships between DMY and 1) Rangeland condition; 2) Lactation order; 3) Schooling years of farmers; 4) Bare ground 
Table 1. Descriptive statistics results for the variables considered in the study.

\begin{tabular}{cccccc}
\hline & $\mathrm{N}$ & Minimum & Maximum & Mean & Std. Error \\
\hline Daily milk yield & 2474 & 0,65 & 15,00 & 6,29 & 0,05 \\
Schooling years of farmers & 2474 & 0,00 & 11,00 & 5,14 & 0,05 \\
Rangeland condition & 2474 & 2,37 & 4,18 & 3,50 & 0,01 \\
Concentrate supplement & 2474 & 0,00 & 1,00 & 0,53 & 0,01 \\
Access to water & 2474 & 0,00 & 1,00 & 0,80 & 0,01 \\
Shading shelter & 2474 & 0,00 & 1,00 & 0,12 & 0,01 \\
Indigenous & 2474 & 0,00 & 1,00 & 0,30 & 0,01 \\
Crossbred & 2474 & 0,00 & 1,00 & 0,65 & 0,01 \\
Purebred & 2474 & 0,00 & 1,00 & 0,05 & 0,00 \\
Lactation order & 2474 & 1,00 & 13,00 & 3,58 & 0,04 \\
Bare ground & 2474 & 17,92 & 29,67 & 25,83 & 0,07 \\
\hline
\end{tabular}

Table 2. Effect of some categorical variables on Daily milk yield of grazing cows

\begin{tabular}{cccc}
\hline Categorical Variables & N & Mean & Se(x) \\
\hline Concentrate supplement during grazing season & 2474 & 6,29 & 0,05 \\
Unsupplied & 1174 & 5,79 & 0,06 \\
Supplied & 1300 & 6,75 & 0,07 \\
\hline Closeness of water spots in grazing sites & 2474 & 6,29 & 0,05 \\
Far & 499 & 5,43 & 0,09 \\
Near & 1975 & 6,51 & 0,05 \\
\hline Availability of shading shelter in grazing sites & 2474 & 6,29 & 0,05 \\
Not Exist & 2182 & 6,22 & 0,05 \\
Exist & 292 & 6,87 & 0,16 \\
\hline Breed of grazing cows & 2474 & 6,29 & 0,04 \\
Indigenous & 738 & 5,51 & 0,08 \\
Prossbred & 1618 & 6,72 & 0,05 \\
\hline
\end{tabular}

The average milk yield per cow, on the other hand, was found to be $6.3 \pm 0.04 \mathrm{~kg}$ for the study year. It was $7.2 \pm 0.08$, $6.4 \pm 0.07$ and $5.3 \pm 0.07$ in June, July and August, respectively. It was also 5.5 $\pm 0.08,6.7 \pm 0.05,5.4 \pm 0.22$ for indigenous, crossbred and purebred cows, in respective order. The concentrate supplement increased the milk yield to $1.0 \mathrm{~kg}$ in general $(6.8 \pm 0.07-5.8 \pm 0.07$; Table 2$)$ and the increment was $1.2 \mathrm{~kg}(=5.9 \pm 0.10-4.7 \pm 0.10), 1.0 \mathrm{~kg}(=7.2 \pm 0.08-6.2 \pm 0.07)$ and $3.1 \mathrm{~kg}$ $(=8.0 \pm 0.30-4.9 \pm 0.23)$ in indigenous, crossbred and purebred cows, respectively.

\section{OLS regression analysis results}

The results of the regression analysis of OLS technique with Robust Standard Errors procedure were presented in Table 3.

Table 3. Multiple regression analysis results with robust standard errors procedure

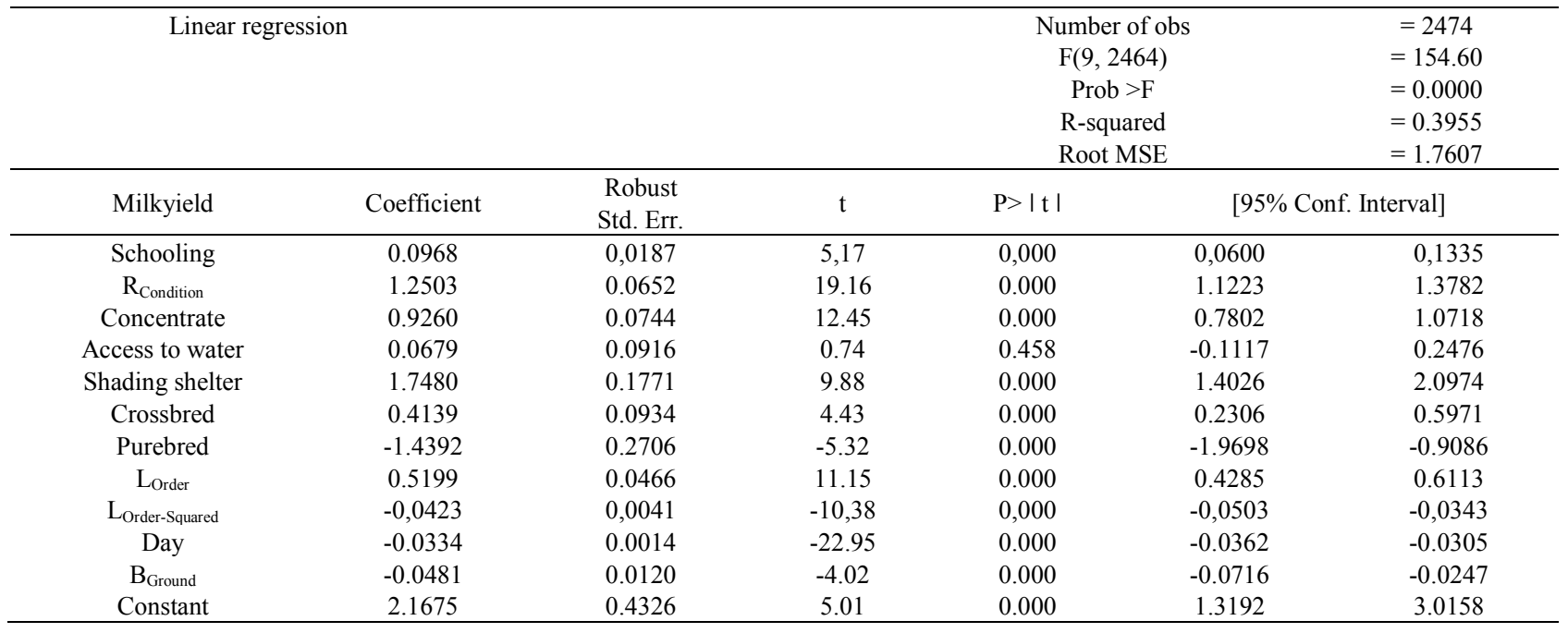


As clearly seen from Table 3 , the signs of the all variables were as expected.

As a socio-economic variable, education is generally expected to have a positive effect on farm effectiveness. Conforming to this it was found that schooling years of the farmers had a significant positive impact on milk yield $(p<0.001)$. It indicates that one year of increment in schooling years of farmers means $0,1 \mathrm{~kg}$ more milk yield per grazing cow. This can be explained with that educated farmers might monitor the herd well and take the timely measures, e.g. measures against diseases and pests. This finding is consistent with the findings of Lockheed et al. [14]. They reported a $7.4 \%$ increase in farm productivity for those having an additional four-year education after primary school.

Daily concentrate supplement during grazing season increased milk yield. More importantly, rangeland condition has similar significant positive effect on milk yield and this effect is stronger than that of supplement feed. An increase in milk yield due to rangeland condition is quite higher than that of concentrate supplement during grazing season. It can be inferred from Table 3 that a possible $10 \%$ increase in rangeland condition will bring about $1.25 \mathrm{~kg}$ milk yield per cow in the study area and the areas with similar conditions. This is 1.34 times more than the milk yield $(0.93 \mathrm{~kg})$ provided by daily one $\mathrm{kg}$ concentrate supplement during the grazing period considered in this study.

Conforming to the literature reporting $[15,16]$, data analysis revealed that lactation order (number of lactation) had a positive significant effect on milk yield since milk yield increases until about the $8^{\text {th }}$ year of age as a result of the increasing development and size of the udder and the increasing body size over that of the first lactation. Inclusion of the quadratic term of the lactation order (lactation order-squared) into the model increased the quality of the model $\left(\mathrm{R}^{2} \text { increased from } 0,3717 \text { to } 0,3863\right)^{1}$. As seen from the Table 3 that the variable lactation order-squared is highly statistically significant $(p<0,000)$. However, the coefficient of this variable is negative as that of lactation order is positive. This suggests that although DMY per head increases with high lactation orders, the rate of increase declines with higher lactation order. ${ }^{2}$

On the other hand, the effect of milking days on milk yield was found to be negative. It should be remembered that milk production rapidly increases to a peak in three to eight weeks postpartum and it gradually declines until drying off [17]. In the study area, calving occurs in February and March and rangeland grazing starts by the second half of May [5]. That is, the grazing season starts, at the earliest, on the $60^{\text {th }}$ or at the latest, on the $90^{\text {th }}$ day of lactation. So, the grazing period comes up to the time of gradual decrease in daily milk yield, which explains the negative sign of milking days.

1 An additional quality improvement was achieved $\left(\mathrm{R}^{2}\right.$ increased from $0,3863$ to 0,3955$)$ with inclusion of schooling variable into the model.

2 That is, holding the other variables constant if we take the derivative of milk yield with respect to lactation order we will obtain $0,5199-0,0846 L_{\text {Order }}$ which shows that the rate of change of milk yield with respect to lactation order declines at a rate of 0,0846 per additional lactation [6].
Moreover, when comparing to local animals, crossbred ones yield significantly more milk during grazing season. However, this effect is in opposite direction for purebred cows $(\mathrm{p}<0.01)$ since they are much heavier and not suitable for grazing conditions of the region (Table 3).

Another two important factors examined in the model are the closeness of the drinking water sources and the availability of shading shelter in the grazed site. Although not significant, closeness of the water spot has positive effect on milk yield because water is the most important nutritional factor in milk production [18]. Conforming this finding, Khan et al. [19] reported a decrease in daily milk production more than $50 \%$ between the dairy cow groups with free and restricted (once a day) access to drinking water. As known, cattle drink water to lower their body temperature so especially during hot weathers accessibility of drinking water for animals in the grazed sites is of great importance. Accordingly, in the present study, it is seen that closeness of the drinking water spot to the grazed site may increase the milk yield in $0.07 \mathrm{~kg}$ per cow.

Heat stress is an important welfare issue and it causes decreases in milk yield due to low feed intake and the shift in blood flow towards peripheral tissues for cooling the body which may alter the nutrient metabolism [20]. Pinarelli [21] reported a $17 \%$ decrease in milk yield due to heat stress. For that reason, provision of shading facility is an important welfare issue in cases that ambient temperature exceeds $24^{\circ} \mathrm{C}$ and the relative humidity exceeds $70 \%$ [22]. In relation to this issue another rangeland attribute examined in this study is the shading facility available at the grazed sites. In the study area during grazing season, relative humidity is not a problem causing stress but temperature can exceed the limits up to $35^{\circ} \mathrm{C}$ [23]. According to the results, the effect of shading facility existence in the grazed site is significant $(p<0,01)$ and it can be inferred from the results that it contributes to the daily milk yield in about $1,75 \mathrm{~kg}$ per head in the present study (Table 3).

\section{Conclusions}

With a special emphasis on rangeland conditions, the aim of this article was to raise awareness on how influential the relevant factors are on daily cow milk yield at farm level. Data analysis yielded meaningful results since the signs of all variables in the model were as expected and could be explained.

According to results, it was clearly demonstrated that RC was one of the most important factors affecting daily milk yield per lactating cow during grazing season. Study results suggest that a 10 percent upward or downward shift in RC ultimately cause an increment or decrement of daily $1.25 \mathrm{~kg}$ in milk yield of the grazing cows.

The study also revealed some other important findings regarding rangeland management and RRIs. In a generally accepted policy to increase milk yield per head of cow, a great effort has been devoted to cattle breed improvement 
since the beginning of the republican era in Turkey, using pure-bred bull semen through either natural service or artificial inseminations. This approach may be correct in intensive dairy production but, as study findings indicate, local or at most crossbreed animals, should be used in extensive dairy cattle production utilising vast natural rangeland assets.

Contrary to common opinion, another remarkable finding on the other hand, is that supplement feed during grazing season, except the times early and late in the grazing season, is not feasible in spite of its positive effect on milk yield. So, extension agents should exclude supplement use suggestions to farmers from their agenda. According to indigenous knowledge farmers have already been using supplement early and late in grazing season when rangeland forage is not sufficient [5].

Furthermore, provision of a shading facility is an important welfare issue in cases where ambient temperature exceeds $24^{\circ} \mathrm{C}$ and the relative humidity exceeds $70 \%$ [22]. Although relative humidity is not a problem causing stress, temperatures can exceed the limits, up to $35^{\circ} \mathrm{C}$ [23], during grazing season in the study area. For that reason, shading shelter constructions are important components in RRIs and the effect of shading on daily milk yield was found to be significant in this study. It was revealed that availability of a shading facility in a grazing site may cause an upward shift of $1.75 \mathrm{~kg}$ milk yield per cow. For that reason, although there are different measures to alleviate the stressful effects of a hot climate [24], cited in [25], shading shelters are the only alternative to be considered in rangelands and should certainly be taken into account in RRIs. To this end, natural shading sources should be given first priority in such investments since they are the most effective and more preferred by cattle rather than constructed structures [26] because they provide a cooling effect in addition to protection from sunlight [27], cited in [25]. However, trees should be evenly distributed in grazing sites to prevent congregation. Otherwise, congregating animals will cause erosion of the soil until roots are exposed, which may result in the death of trees.

The findings of this study, especially those related to rangeland attributes on milk yield, were found to be statistically significant and can be explained by the reported literature. However, present study findings need to be proven by long-term and more robust studies.

\section{Acknowledgements}

The results presented in this paper are one of the outputs from the research project numbered TAGEM/HAYSÜD /05/01/01/01, and entitled 'Analysis of the Factors Affecting Milk Production and Live Weight Gain in the Cattle Farms Dependent on Natural Grazing Lands in Erzurum'. The author extends his gratitude to the Rangeland Team of Eastern Anatolia Agricultural Research Institute for their valuable work on vegetation surveys and rangeland condition calculations. The author is also thankful to Dr. Funda UNCU of Economics and Administrative Sciences Faculty, Dicle University, for her valuable time in reviewing the article regarding econometric analysis.

\section{REFERENCES}

[1] Turkish Statistical Institute [Internet]. Ankara: The Institute; c2015. General Agricultural Census, 2001. [cited 2013 May 15]; Available from: www.turkstat.gov.tr

[2] Koç A, Çakal Ş. Comparison of some rangeland canopy coverage methods. International Soil Congress Natural Resource Management for Sustainable Development; 2004 Jun 7-10; Erzurum.

[3] De Vries DM, De Boer THA, Diver JPP. Evaluation of grassland by botanical research in the Netherlands. In: Proceedings of the United Nationals Scientific Conference on the Conservation and Utilization of Resources. c1951. Volume 6, p. 522-24.

[4] Koç A, Gökkuş A, Altın, M. Mera durumu tespitinde dünyada yaygın olarak kullanılan yöntemlerin mukayesesi ve Türkiye için bir öneri. Türkiye 5. Tarla Bitkileri Kongresi; 2003 Ekim 13-17; Diyarbakır.

[5] Kara A, Çakal Ș, Tavlaş A, Yazıcı A, Aygün C, Avağ A. Customs and problems in exploiting meadow and pastures in north-east Anatolia. Alinteri Zirai Bilimler Dergisi. 2009. 16, $7-18$.

[6] Gujarati DN. Basic Econometrics. $3^{\text {rd }}$ ed. New York: McGraw-Hill; c1995.

[7] Neter J, Wasserman W, Kutner MH. Applied linear regression models. $2^{\text {nd }}$ ed. Boston: Richard D Irwin; c1989.

[8] Park HM. Linear regression models for panel data using SAS, Stata, LIMDEP, and SPSS. Working Paper [Internet]. The University Information Technology Services (UITS), Center for Statistical and Mathematical Computing, Indiana University: 2009 [cited 2009 July 30]; [about two screens]. Available from: http://www.indiana.edu/ statmath/ stat/all/ panel

[9] Park HM. Univariate analysis and normality test using SAS, Stata and SPSS. Working Paper [Internet]. The University Information Technology Services (UITS), Center for Statistical and Mathematical Computing, Indiana University: 2009 [cited 2009 July 30]; [about two screens]. Available from: http://www.indiana.edu/ statmath/stat/all/normality/in dex.html

[10] PROPHET StatGuide: Do your data violate linear regression assumptions? [Internet]. [Place unknown];[date unknown]. [cited 2013 March 11]; [about one screen]. Available from: http://www.basic.northwestern.edu/statguidefiles/mulreg_ass _viol.html

[11] Lumley T, Diehr P, Emerson S, Chen L. The importance of the normality assumption in large public health data sets. Annu. Rev. Public Health. 2002. 23:151-69.

[12] Callaghan KJ Chen J. 2008. Revisiting the collinear data problem: an assessment of estimator 'III-conditioning' in linear regression. Practical Assessment Research \& Evaluation [Internet]. 2008 [cited 2009 July 30]; 13(5): 1-5. Available from: http://pareonline.net/getyn.asp 
[13] Gujarati DN. Econometrics by example. USA: McGraw-Hill; c2011.

[14] Lockheed ME, Jamison DT, Lau LJ. Farmer education and farm efficiency: a survey. In: 'Education and Income: A Background Study for World Development Report'. (Ed. T. King.) pp. 52-111. World Bank: Washington D.C. U.S.A.

[15] Türkyılmaz MK, Bardakçığlu HE, Nazlıgül A. Effect of Some Factors on Milk Yield in Holstein Cows, Kafkas Univ. Vet Fak. Derg. 2005, 11(1): 69-72.

[16] Bognar A, Stanciu G, Cziszter LT, Acatincăi S, Tripon I, Gavojdian D, Baul S, Tetileanu R. Lactation order effects on milk production in Romanian black and white cows from Timiş county, Scientific Papers: Animal Science and Biotechnologies. 2010. 43(2). 213-16.

[17] Kaya İ, Kaya A. Parameter estimate for persistency of lactation and relationship of persistency with milk yield in Holstein cattle. 1. Factors affecting persistency of lactation. Hayvansal Üretim. 2003. 44: 76-94.

[18] Çakır A, Aksoy A, Haşimoğlu S. Applied feeding of farm animals. Publications No: 179. Erzurum: Atatürk University; c1995.

[19] Khan R, Qureshi MS, Mushtaq A, Ghufranullah and Naveed A. Effect of quality and frequency of drinking water on productivity. The Journal of Animal and Plant Sciences.2012. 22(2 Suppl.): 96-101.
[20] West JW. Effects of heat stress on production in dairy cattle. J. Dairy Sci. 2003. 86: 2131-44.

[21] Pinarelli C. The effect of heat stress on milk yield. Latte. 2003. 28(12): 36-38.

[22] Silanikove N. Effects of heat stress on the welfare of extensively managed domestic ruminants. Livestock Production Science. 2000. 67:1-18.

[23] Turkish State Meteorological Service [Internet]. Ankara: The Service: c2013. Climatic Data. Meteorological Data Archive System of Turkey (TÜMAS). [cited 2013 May 17]; Available from: www.mgm.gov.tr

[24] Shibata M. Factors affecting thermal balance and production of ruminants in a hot environment- A review. Memories of National Institute of Animal Industry No. 10; c1996.

[25] Kurihara M, Shioya S. Dairy cattle management in a hot environment. Extension Bulletin-Food \& Fertilizer Technology Center, No. 529; c2003.

[26] Higgins SF, Agouridis CT, Wightman S J. Shade options for grazing cattle. Lexington: Cooperative Extension Service, University of Kentucky College of Agriculture; c2011.

[27] Hahn GL. Housing and management to reduce climatic impacts on livestock. Jour. Animal Science. 1981. 52:175-86. 